\title{
Spatial Redistributions of Regional Economic Activity in Central Java (Direct Error Correction Model Causality Approach)
}

\author{
Jihad Lukis Panjawa ${ }^{1)}$, Bhimo Rizky Samudro' \\ ${ }^{1)}$ Faculty of Economics and Business, Universitas Tidar \\ ${ }^{2)}$ Faculty of Economics and Business, Universitas Sebelas Maret \\ Corresponding Author: jipanjawa@untidar.ac.id
}

Recieved: December 2019 | Revised: March 2020 | Accepted: April 2020

\begin{abstract}
This study analyzes spatial inequality through a causal relationship between inequality and economic growth within-recidency, between-recidency and overall in Central Java.The analytical tool used is the Direct Error Correction Model causality. This study shows that spatial concentrations throughout the observation period are quite high. In the 2001-2008 period there was an increasing tendency for spatial concentration, reflecting the decline in the distribution of the Gross Regional Domestic Product (GRDP) share of districts and cities in Central Java. We also obtained similar findings in a number of regions both within and between-recidency. Post-2008, spatial concentration tends to decrease, indicating the distribution of the Gross Regional Domestic Product share. Other findings indicate a one-way relationship shown economic growth towards inequality. Another important contribution is that economic growth in inequality only occurs in the long term. Thus there has been convergence because of the increase in economic growth which is able to reduce inequality in all areas of Central Java, including within and between-recidency. This proves that during the implementation of regional autonomy there is a spread effect greater than the backwash effect in Central Java, including within and between-recidency.
\end{abstract}

Keywords: Economic Growth; Spatial Inequality; Regional Development

JEL classification: O40, R12, R58

How to Cite: Panjawa J., L., Samudro B., R. (2020). Spatial Redistributions of Regional Economic Activity in Central Java (Direct Error Correction Model Causality Approach). Jurnal Ekonomi Pembangunan: Kajian Masalah Ekonomi dan Pembangunan, 21(1). 1-13. doi:https://doi.org/10.23917/ jep.v21i1.9587

DOI: https://doi.org/10.23917/jep.v21i1.9587

\section{Introduction}

Significant development inequality is often overlooked in the approach with an emphasis on high macroeconomic growth (Gross Domestic Product/GDP). The problem of inequality has never looked at the size and level of development of an area(Rustiadi, Saefulhakim, \& Panuju, 2011). Between-regional inequality are polemic in development. Between-regional inequality is the center of attention in the issue of inequality. between-regional inequality describes the development gap both withwithin- regional and between-regional (Kuncoro, 2011). The diversity of potential natural resources, geographical conditions, the quality of human resources, ethnicities, political situations, history, government policies, economics and administrations are the causes of betweenregional inequality.

Between-regional inequality is decomposed into subgroups including income, other diverse unit characteristics and heterogeneity which give rise to between-regional trends in inequality and inter-sectoral economics in an area (Kuncoro, 
2011; Ramos \& Coimbra, 2009). Some studies of inequality at different levels, ranging from international inequality (Ezcurra \& Pascual, 2008; Habanik, Hostak, \& Kutik, 2013; Postoiu \& Bușega, 2015; Rodriguez-Pose \& Ezcurra, 2010), inter-province outside of Indonesia (Antonescu, 2012; Bonet, 2006; Fitrawaty, Maipita, Hermawan, \& Rahman, 2018; Islam \& Noman, 2015; Wijerathna, Bandara, Smith, \& Naranpanawa, 2014), inter-province in Indonesia (Aritenang, 2014; Fadli, 2014; Mahardiki \& Santoso, 2013; Zakaria, 2013), inter-city outside of Java Island (Arham, 2014; Baransano, Putri, Achsani, \& Kolopaking, 2016; Yuliani, 2015), Inter-city in Java Island (Abdulah, 2013; Kurniawan \& Sugiyanto, 2013), regional (Cahyono, Subroto, \& Anwar, 2017; Suseno, 2015) and inter-sub-district in a city (Nugroho, 2014). There is also research on pre-post-crisis inequality (Đoki, Fröhlich, \& Bakaric, 2016), inequality after regional expansion (Dhyatmika \& Atmanti, 2013) and differences in the conditions of inequality in origin district and newdistrict (Panjawa, Samudro, \& Soesilo, 2018).

In Indonesia, the Sustainable Development Goals (SDGs) include sustainable handling of inequality and economic growth. Referring to the results of the evaluation report of the 2010 2014 Medium Term Development Plan by State Ministry for Development Planning/Bappenas (Bappenas, 2015), Central Java became one of the seven provinces that were of particular concern in the issue of development inequality. The determination of special attention is based on the high income inequality of the community as measured by the uneven Gini Ratio and between-regional development as measured by the Williamson Index.

Various efforts to overcome development problems have been carried out several times such as income distribution and increasing economic growth (Baransano et al., 2016; Fitrawaty et al., 2018; Shobha \& Ambiga Devi, 2014). Inequality and growth are logical consequences in economic development (Dhyatmika \& Atmanti, 2013). Further implications of economic growth are distribution, structural shifts and income distribution.

Studies on economic growth and inequality have different results. Increased economic growth will also exacerbate between-regional inequality (Fadli, 2014; Zakaria, 2013). Contradictory results indicate that high economic growth is believed to be able to improve welfare and minimize inequality between regions (Antonescu, 2012; Yuliani, 2015). In Kuznet's hypothesis, in the early stages of an economic development process, differences in the large between-regional economic growth rate resulted in inequality in between-regional income distribution. In the long run there is convergence, that is when economic conditions reach maturity and assuming free market mechanisms and the mobility of all between-regional production factors without the least obstacles and distortions, the difference in between-regional economic growth rates tends to shrink along with the per capita income level (and its growth rate) the higher the average in each region and ultimately to reduce regional economic inequality (Arsyad, 2010; Isnowati, 2007).

Contrary to the kuznet hypothesis in the long term, Myrdall's theory explains that the long-term development process will exacerbate inequality due to circular cumulative causation (O'Hara, 2008; Samudro, Bloch, \& Salim, 2015). There are two forces that cause a region to experience convergence and divergence such as spread effect and backwash effect. Spread effect that shows the situation in which the development of underdeveloped regions is driven by more developed regions, while the backwash effect shows a situation in which the development of underdeveloped regions is hampered by more developed regions (Rustiadi et al., 2011). The development process requires two elements including mutual growth and equity. In the last few decades, the development paradigm has undergone fundamental shifts and changes. Distortion in the form of errors in the application of development models is the cause. The shift in the development paradigm that is changing is the 
tendency to measure the success of development on a macro basis into regional approaches. By optimally utilizing economic potential will be able to increase equity. In other words, the convergence in determining the region and the center of growth in a more dispersed manner certainly will encourage between-regional equitable development.

There is a lot of discussion about inequality and economic growth in Indonesia even though there are still gaps. Many studies have tackled this topic, but the results are varied and sometimes heterogeneous. By observing from previous studies related to the existence of distortions in the application of the development model related circular cumulative causation (CCC) and trying to use different measurements. The alternative measurement is based on the paradigm shift of macro development, especially economic growth and inequality into the region .Our contribution in this paper is empirical to the rationale for our consideration of the effect on economic growth, inequality and their interaction. In other words, the purpose of this study is to examine spatial inequality, to find out the causal relationship between inequality and economic growth in residency and between-residency, and how big the role is in Central Java, Indonesiausing Direct Error Correction Model Causality Approach.

\section{Methodology}

The scope of this research is one of the provinces in Indonesia, Central Java. The observation period in this study is during the era of regional autonomy which began in 2000 to 2016 . The type of data used is secondary data sourced from journals, reports, and websites such as the Badan Pusat Statistik (BPS-Statistic Indonesia). This research variable is inequality and economic growth based on Gross Regional Domestic Product (GRDP) based on constant prices. Gross Regional Domestic Product (GRDP) is an indicator to determine the economic condition of a region in a certain period and measure economic growth.
Economic growth is the development of activities in an economy where the production of goods and services increases for social prosperity.

The method used in this study is descriptive and quantitative with econometric methodology. We will answer the first research objective regarding the study of spatial inequality using the Theil Entropy index. Theil entropy index is used as an analytical tool used to analyze the paradigm shift of development from macro to regional. Regionally by grouping based on residency. According to Kuncoro (2013)an analysis of the spatial distribution of real income is done to determine the pattern of concentration of real income distribution in Central Java. Theil Entrophi Index offers several advantages. First, it will be useful to analyze trends in geographical concentration over a period of time, and the second is to examine a more detailed picture of the spatial gap. The main advantage of this index is that at one point in time this index provides a measure of the degree of concentration of spatial distribution in a number of regions and sub-regions. The most significant characteristic of the Theil Entropy index is that this index can distinguish Between-regional inequality and inregion inequality. Based on the explanation of the advantages of the Theil Entropy index, the Theil Entropy index is appropriate for analyzing between-regional inequality regarding the pattern of concentration of income distribution in Central Java. The following is the Theil Entrophi index formula.

$$
I(y)=\sum_{i=1}^{N} y_{i} \log \frac{y_{i}}{N}
$$

I (y) represents the overall Entrophi index of the spatial inequality of Central Java; yi represent the share of districts / cities in the total Gross Regional Domestic Product (GRDP) of Central Java; $\mathrm{N}$ represents the total number of districts / cities in Central Java. To measure the spatial income inequality between residencies in Central Java, the formula can be developed: 


$$
I(y)=\sum_{r=1}^{R} Y_{r} \log \frac{Y_{r}}{N_{r} / N}+\sum_{r=1}^{R} Y_{r}\left[\sum_{i \in r}^{R} \frac{y_{i}}{Y_{r}} \log \frac{y_{i} / Y_{r}}{N_{r}}\right]
$$

Yr represents the Gross Regional Domestic Product (GRDP) share of all districts / cities in the residence $\mathrm{r}$; $\mathrm{Nr}$ represents the number of Regencies / Cities in the residence $r$; and $R$ is the total number of residences in Central Java. The total residency in this study, grouped according to Law No.10 of 1950 concerning the establishment of the Central Java Province which covers the Residency of Semarang, Pati, Pekalongan, Banyumas, Kedu, and Surakarta. This grouping aims to compare between and within a Residency in Central Java. The first part in equation 2 measures the degree of inequality according to the share of residency Gross Regional Domestic Product (GRDP) in Central Java (betweenresidency), while the second part measures the degree of difference in the share of Regency / City Gross Regional Domestic Product (GRDP) in each residency (within-residency), which is weighted by the Gross Regional Domestic Product (GRDP) share entire Regency / City in Central Java. The Enthropy Index includes decomposition into spatial inequality between regencies / cities in one residency, calculated for 35 regencies / cities in Central Java and 6 (six) residencies.

This helps us in answering the objectives of the next research in analyzing the causal relationship between within-residency and between-residency economic inequality and growth, and how much role it plays in using a quantitative approach with econometric methodology. In this methodology, we use the Direct Error Correction Model analysis tool. According to Gujarati and Porter (2009), causality or direction of influence is justified by the theory used for model formation. Basically, research with regression analysis is not only an attempt to express the relationship between variables that empirically occur in the real world, but also an attempt to justify a theory. Causality analysis, although its implementation must still be guided by theory, has flexibility in determining the direction of causality of functional relationships between two economic variables.

By modifying as appropriate the Error Correction Model in general, Direct Error Correction Model causality assumes the existence directly of a long-term cause-effect relationship between two or more economic variables, however, in the short term what happens is disequilibrium. With the error correction mechanism, a proportion of disequilibrium in a period is corrected in the next period. The adjustment process is a tool to reconcile short and long term behavior. Based on this concept, long-term relationships can be estimated through short-term relationships. Therefore, the Direct Error Correction Causality Model is a causality test using regression analysis of the Direct Error Correction Model, which is done on two reciprocal variables.

$$
\begin{aligned}
& I_{t}^{*}=\beta_{0}+\beta_{1} Y_{t}+\varepsilon_{t} \\
& Y_{t}^{*}=\beta_{0}+\beta_{1} I_{t}+\varepsilon_{t}
\end{aligned}
$$

Error Correction is an error correction mechanism by minimizing the cost function. The minimization, structuring and parameterization process will produce a standard short-term Direct Error Correction equation.

$$
\begin{aligned}
& \Delta I_{t}=\alpha_{1} \Delta Y_{t}-\lambda\left(I_{t-1}-\beta_{0}-\beta_{1} Y_{t-1}\right)+v_{t} \\
& \Delta Y_{t}=\alpha_{1} \Delta I_{t}-\lambda\left(Y_{t-1}-\beta_{0}-\beta_{1} I_{t-1}\right)+v_{t}
\end{aligned}
$$

Prioriously, $\alpha_{1}$ is defined as a shortterm coefficient; $\beta_{1}$ represents the long term coefficient. $\lambda$ represents the adjustment coefficient with values ranging from 0 to $1(0<$ $\lambda<1)$. Error correction consists of two elements; they are corrections made by considering current conditions (short term) and corrections made to past mistakes. Structuring and parameterizing the Direct Error Correction causality equation The standard short-term model will produce the Direct Error Correction Model causality estimator: 
$\Delta I_{t}=\gamma_{0}+\gamma_{1} \Delta Y_{t}+\gamma_{2} Y_{t-1}+\gamma_{3} E C T+\omega_{t}$

$\Delta Y_{t}=\gamma_{0}+\gamma_{1} \Delta I_{t}+\gamma_{2} I_{t-1}+\gamma_{3} E C T+\omega_{t}$

where: I represents spatial inequalities with measurements of the Theil Entropy index for within-residency, between-residency and total spatial inequality of the province; $\mathrm{Y}$ represents economic growth; $\gamma_{0}$ represents a short-term constant; $\gamma_{0}=\lambda \beta_{0}$ serves to find a long-term constant; $\quad \gamma_{1}=\alpha_{1}$ represents the short-term coefficient of influence; $\gamma_{2}=-\lambda\left(1-\beta_{1}\right)$ serves to find long-term coefficients; $\gamma_{3}=\lambda$ represents the adjustment coefficient; ECT $=Y_{t-1}-I_{t-1}$ for equations with the dependent variable spatial inequality, while ECT $=I_{t-1}-Y_{t-1}$ serves to find the equation with the dependent variable of economic growth. $\mathrm{ECT}=$ error correction term.

\section{Results and Discussion}

Spatial inequality indicates regional and between-regional development gaps. Development gap refers to the centralization of economic activities in a particular region. Spatial inequality is represented by theil entropy index related to the development of the gap in spatial distribution measured by the share of gross regional domestic product.

Figure 1 explains the trends in spatial inequality in residency. Within-residency spatial inequality increased (divergent) in 2001-2008. This shows an increase in spatial concentration of the share of gross regional domestic products. In Figure 1, the trend after 2008 shows a decreasing theil entropy index. The decreased spatial withinresidency concentration experiences convergent conditions, meaning that there is no degree of within-residency difference observed from the spread of gross regional domestic product share.

A pattern similar to within-residency spatial inequality also occurs between spatial-Residency spatial inequality (see Figure 2). The spatial concentration between-Residency has increased from 2001-2008. This reflects an increasing degree of difference between Residency, which is seen from the share of gross regional domestic product. In the period after 2008, there was a spread of the share of gross regional domestic products. That is, the decreasing spatial concentration betweenResidency.

Figure 1, 2 and 3 explain theil withinresidency entropy index trend, between-Residency and overall in Central Java has the same pattern and forms a "reverse U" curve. The spatial concentration increase that occurred at withinresidency and between-Residency from 2001-2008 also had a total impact on Central Java. This reflects an increasing degree of difference in the districts and cities of Central Java which is seen from the share of gross regional domestic products. In 2001-2008, it was shown that there was a decrease in the spread of gross regional domestic product share of districts and cities in Central Java. In the period after 2008, there was a spread of the share of gross regional domestic products. That is, decreasing spatial concentration so that it is no longer concentrated in an area (convergent).

At the beginning of the development of divergent conditions (increasing income inequality) as experienced regionally based on withinresidency, between-residency and overall in Central Java caused by the implementation of a policy called regional autonomy. Broadly discoursing, the autonomy policy is the fit, authority, and commitment of the autonomous region to regulate and manage their matters related to government and the interests of the people under applicable laws and regulations. The beginning of regional autonomy will increase economic growth quickly in developed regions compared to other regions that are lagging. The logical consequence is that it is more efficient in developed regions compared to other regions that are lagging in the use of resources. Besides, differences in regional potential are very large, differences in geographical conditions, employment, and the lack of fluency of goods and people between regions. This phenomenon makes the development disparities between regions higher, so its package is said that in the short-run the backwash effect is greater than the spread effect. 
Avalaible online at http://journals.ums.ac.id, Permalink/DOI: 10.23917/jep.v21i1.9587

Jurnal Ekonomi Pembangunan: Kajian Masalah Ekonomi dan Pembangunan, 21 (1), 2020, 1-13

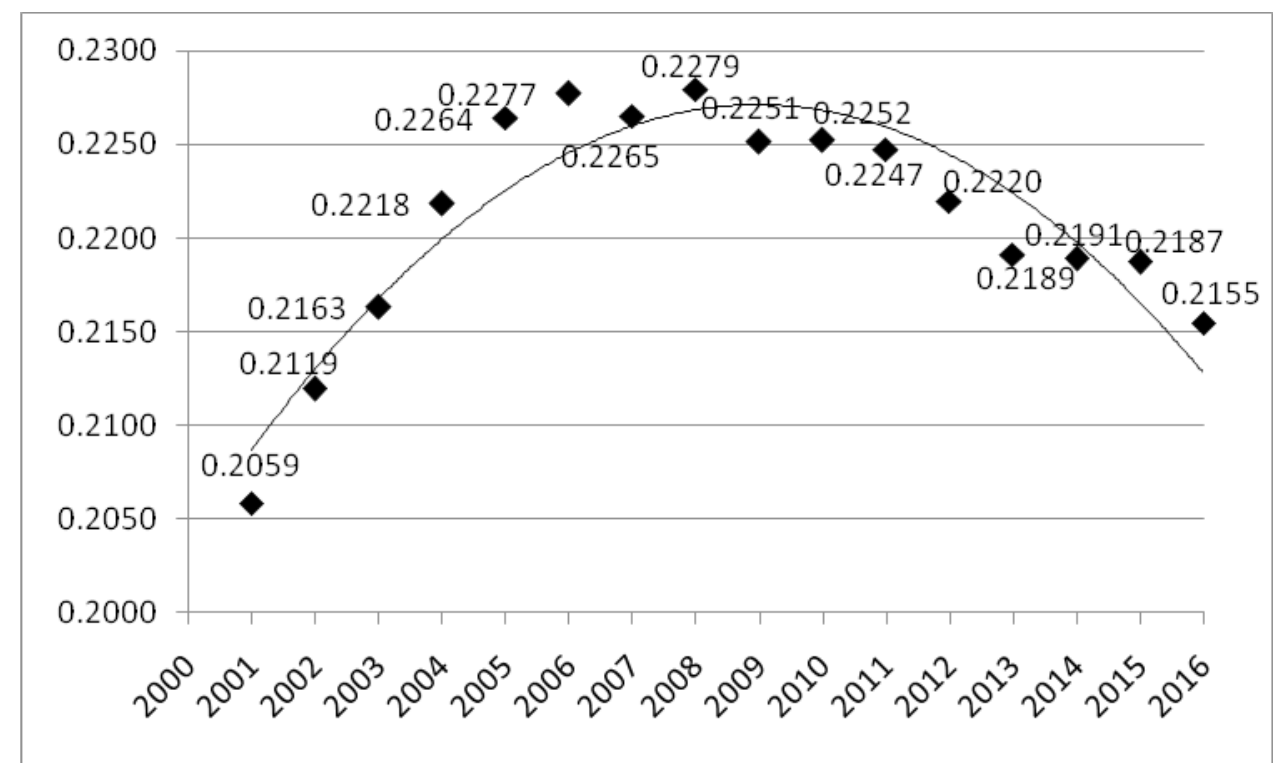

Figure 1. Within-residency spatial inequality

Source: Statistics Indonesia, processed

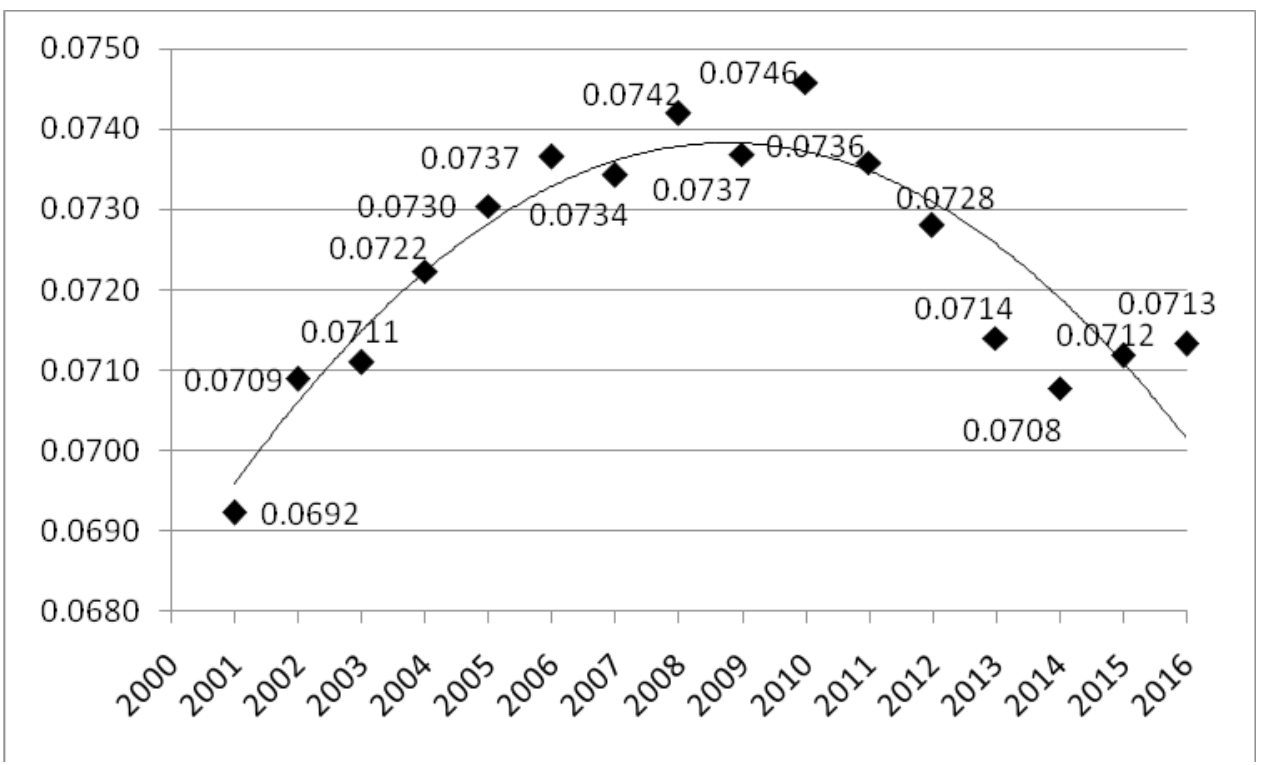

Figure 2. Between-residency spatial inequality

Source: Statistics Indonesia, processed

However, in the long-run, the condition that occurs is the spread effect is greater than the backwash effect. The effect of the spread effect shows that developed regions that have become centres of growth can encourage disadvantaged regions to create new socio-economic activities with their own ability to create facilities independently and finally the surrounding areas also develop to form new growth. Regional groupings based on residency have a positive impact concerning equity. Lagging regions are more efficient in utilizing the factors of production to increase productivity. Besides, the existence of regional autonomy policy makes regions more aware of their local needs, so that they package set policies according to the needs of each region. 
Avalaible online at http://journals.ums.ac.id, Permalink/DOI: 10.23917/jep.v21i1.9587

Jurnal Ekonomi Pembangunan: Kajian Masalah Ekonomi dan Pembangunan, 21 (1), 2020, 1-13

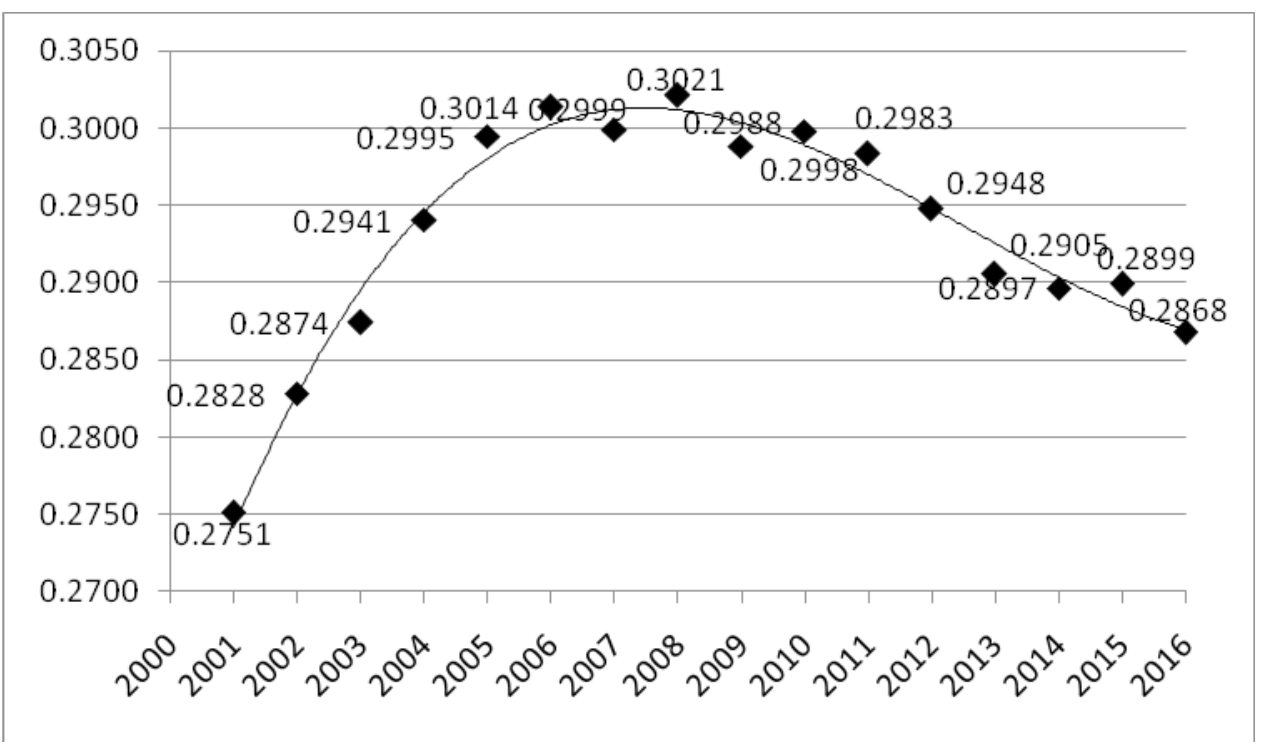

Figure 3. Total Entropy Index of Spatial Inequality (Province)

Source: Statistics Indonesia, processed

Table 1. Diagnosis Test

\begin{tabular}{llccc}
\hline \multirow{2}{*}{ Diagnosis Test } & \multicolumn{2}{c}{ Dependent Variable Spatial Inequality } \\
\cline { 3 - 4 } & & $\begin{array}{c}\text { Within- } \\
\text { Residency }\end{array}$ & $\begin{array}{c}\text { Between- } \\
\text { Residency }\end{array}$ & Province \\
\hline Normality test & Jarque-Bera & 0,3558 & 1,3536 & 0,0083 \\
Breusch-Godfrey Serial & Prob. & 0,8371 & 0,5082 & 0,9959 \\
Correlation LM Test & Chi-Square & 1,2384 & 0,3001 & 0,9086 \\
Heteroskedasticity Test (White) & Prob. & 0,5384 & 0,8607 & 0,6349 \\
& Chi-Square & 10,0570 & 5,9549 & 12,3871 \\
Ramsey Reset Test & Prob. & 0,2611 & 0,5450 & 0,1347 \\
& F-Stat & 0,2786 & 0,0006 & 0,0818 \\
Normality test & Prob. & 0,6092 & 0,9818 & 0,7807 \\
\multirow{2}{*}{ Breusch-Godfrey Serial } & Jarque-Bera & 0,2312 & 0,5191 & 0,2998 \\
Correlation LM Test & Prob. & 0,8908 & 0,7714 & 0,8608 \\
Heteroskedasticity Test (White) & Chi-Square & 5,7678 & 3,2073 & 5,4147 \\
& Chi-Square & 0,0559 & 0,2012 & 0,0667 \\
Ramsey Reset Test & Prob. & 11,6292 & 12,5319 & 12,3701 \\
& F-Stat & 0,2350 & 0,1850 & 0,1932 \\
& Prob. & 0,6700 & 0,2624 & 0,6567 \\
\end{tabular}

Note: ${ }^{*}$ significance at $\alpha 10 \% ;{ }^{* *}$ significance at $\alpha 5 \% ; * * *$ significance at $\alpha 1 \%$

Source: Regression Results

The Direct Error Correction Model causality analysis is used to analyze more deeply the relationship between spatial inequality and within-residency economic growth, betweenResidency and how big it is at the provincial level of Central Java during the era of regional autonomy. To get a valid estimator, some supporting assumptions must be fulfilled. In table 1 shows that the supporting assumptions are fulfilled, meaning that the residuals are normally distributed, there is no problem of autocorrelation, homoskedasticity and exact model specifications. By assuming the fulfillment of a diagnostic test is the same as the fulfillment of stationarity and 
cointegration in the causal analysis of the Direct Error Correction Model.

Not only is the diagnostic test to be fulfilled, there are still the next steps used in the requirements of the model. The conditions that must be fulfilled to be called Direct Error Correction Causality Model are by analyzing the adjustment coefficient or commonly called lamda $(\lambda)$ indicated by the error correction term (ECT) coefficient with values ranging from 0 to $1(0<\lambda$ $<1)$ and significant. Based on table 2 shows that the adjustment coefficient ranges from 0 to 1 and is significant. Therefore, this study which is based on table 1 and table 2 can be concluded that it is feasible to use the Direct Error Correction Model causality estimator.

Table 2. Causality Results of Direct Error Correction Model

\begin{tabular}{|c|c|c|c|c|}
\hline \multirow{2}{*}{$\begin{array}{c}\text { Dependent } \\
\text { Variable }\end{array}$} & \multicolumn{4}{|c|}{ Independent Variable : Economics Growth } \\
\hline & Variable & Coefficient & t-Statistic & Prob. \\
\hline \multirow{6}{*}{$\begin{array}{l}\text { Withwithin- } \\
\text { residency } \\
\text { of Spatial } \\
\text { Inequality }\end{array}$} & $\mathrm{C}$ & 0,0813 & 4,5967 & $0,0008^{* * *}$ \\
\hline & Short Term & $-0,0010$ & $-0,7442$ & 0,4724 \\
\hline & Long Term & $-0,2581$ & $-3,2544$ & $0,0077 * * *$ \\
\hline & $\operatorname{ECT}(-1)$ & 0,2529 & 3,1799 & $0,0088^{* * * *}$ \\
\hline & R-square & 0,7428 & F-Statistic & 10,5866 \\
\hline & DW-Statistic & 1,8427 & Prob.F & $0,0014^{* * *}$ \\
\hline \multirow{6}{*}{$\begin{array}{l}\text { Between- } \\
\text { Residency } \\
\text { of Spatial } \\
\text { Inequality }\end{array}$} & $\mathrm{C}$ & 0,0249 & 3,1016 & $0,0101^{* *}$ \\
\hline & Short Term & $-0,0002$ & $-0,4229$ & 0,6805 \\
\hline & Long Term & $-0,2572$ & $-2,3450$ & $0,0388^{* *}$ \\
\hline & $\operatorname{ECT}(-1)$ & 0,2559 & 2,3320 & $0,0397 * *$ \\
\hline & $\mathrm{R}$-square & 0,5932 & F-Statistic & 5,3467 \\
\hline & DW-Statistic & 2,1552 & Prob.F & $0,0162^{* *}$ \\
\hline \multirow{6}{*}{$\begin{array}{l}\text { Province } \\
\text { of Spatial } \\
\text { Inequality }\end{array}$} & $\mathrm{C}$ & 0,1045 & 4,5946 & $0,0008^{* * *}$ \\
\hline & Short Term & $-0,0012$ & $-0,7423$ & 0,4735 \\
\hline & Long Term & $-0,2537$ & $-3,3023$ & $0,0070 * * *$ \\
\hline & $\operatorname{ECT}(-1)$ & 0,2472 & 3,2072 & $0,0083^{* * *}$ \\
\hline & $\mathrm{R}$-square & 0,7531 & F-Statistic & 11,1881 \\
\hline & DW-Statistic & 2,0299 & Prob.F & $0,0011^{* * *}$ \\
\hline \multirow{6}{*}{$\begin{array}{l}\text { Withwithin- } \\
\text { residency } \\
\text { of Spatial } \\
\text { Inequality }\end{array}$} & $\mathrm{C}$ & 6,6347 & 1,0484 & 0,3170 \\
\hline & Short Term & $-48,0717$ & $-0,7442$ & 0,4724 \\
\hline & Long Term & $-13,8054$ & $-0,5744$ & 0,5773 \\
\hline & $\mathrm{ECT}(-1)$ & 0,7574 & 1,9003 & $0,0839^{*}$ \\
\hline & $\mathrm{R}$-square & 0,3072 & F-Statistic & 1,6255 \\
\hline & DW-Statistic & 2,4042 & Prob.F & 0,2399 \\
\hline \multirow{6}{*}{$\begin{array}{l}\text { Between- } \\
\text { Residency } \\
\text { of Spatial } \\
\text { Inequality }\end{array}$} & $\mathrm{C}$ & 4,8428 & 0,6965 & 0,5006 \\
\hline & Short Term & $-81,6365$ & $-0,4229$ & 0,6805 \\
\hline & Long Term & $-24,0649$ & $-0,2786$ & 0,7857 \\
\hline & $\operatorname{ECT}(-1)$ & 0,6364 & 1,8048 & $0,0985^{*}$ \\
\hline & $\mathrm{R}$-square & 0,2838 & F-Statistic & 1,4531 \\
\hline & DW-Statistic & 2,3082 & Prob.F & 0,2806 \\
\hline \multirow{6}{*}{$\begin{array}{l}\text { Province } \\
\text { of Spatial } \\
\text { Inequality }\end{array}$} & $\mathrm{C}$ & 6,9159 & 1,0155 & 0,3317 \\
\hline & Short Term & $-40,0449$ & $-0,7423$ & 0,4735 \\
\hline & Long Term & $-11,3542$ & $-0,5799$ & 0,5737 \\
\hline & ECT(-1) & 0,7698 & 1,8741 & $0,0877^{*}$ \\
\hline & $\mathrm{R}$-square & 0,3070 & F-Statistic & 1,6241 \\
\hline & DW-Statistic & 2,3920 & Prob.F & 0,2402 \\
\hline
\end{tabular}

Note: * significance at $\alpha 10 \% ;{ }^{* *}$ significance at $\alpha 5 \% ; * * *$ significance at $\alpha 1 \%$

Source: Regression Results 
In Table 2 shows the results in the short term and long term spatial inequalities do not affect significantly to economic growth in the region and the period of observation. On the same Table also shows that economic growth in the short term does not effect the spatial inequality significantly to, but in the long run economic growth significant negative effect against the spatial inequality within-residency, betweenresidency and Central Java province during the period of observation. The regression test results show interesting findings; only one-way relationships occur. The one-way relationship is economic growth towards spatial inequality in the area and period of observation. The results of this study indicate that the important role of increasing economic growth was able to reduce spatial inequality in the study area during the observed period. Another important contribution is the effect of economic growth on inequality does not occur in the short term but only occurs in the long term.

Various government policies, especially the enactment of the regional autonomy law, can be seen as an effort to overcome inequality and between-regional development inequalities. Regional autonomy is seen as one of the important aspects that can reduce development inequality between regions.

The policy of regional autonomy is expected so that the regions will be more independent in their regional arrangements. Fiscal decentralization can bring great economic efficiency in the allocation of resources between public sectors. Fiscal decentralization can improve economic efficiency since local governments are closer to local communities than the central government so that local governments will be more responsive to local needs and preferences. Thus, with fiscal decentralization able to reduce between-regional inequality. The increasing trend of inequality is due to the initial implementation of the regional autonomy policy stated in Law No.22 of 1999 concerning regional government. The implementation of this policy provides a fairly high gap, because in some fast-growing and fastgrowing regions, it is better prepared and able to utilize the existing potential resources, efficiently and independently compared to developing and underdeveloped regions. Law No.22 of 1999 was replaced with Law No. 32 of 2004 and refined into Law No. 23 of 2014 had a good impact in reducing between-regional inequality.

This proves that during the implementation of regional autonomy there has been a spread effect impact greater than the impact of the backwash effect in Central Java including withinresidency and between-Residency. The spread of gross regional domestic product share. Readiness and adaptation of the regions is mature in order to increase economic activity and overcome development problems in their respective regions. Increased economic activity is expected to be able to increase economic growth in all regions by optimizing the existing Source power potential, so as to be able to spread the share of gross regional domestic products (convergent). It is necessary to develop and optimize the role of growth cores by attracting investment to growth cores and peripheries, including through land with clean and clear status, such as accessibility; availability of natural resources; availability of supporting infrastructure (roads, ports, airports, electricity and clean water), incentives and regulations. Besides, institutional management of growth cores and peripheries by increasing within and between-centre connectivity through the use of technology in growth cores and peripheries, supporting policies and regulations for the development of growth cores and peripheries.

Some previous studies support the results in this study. Insignificant inequality on economic growth is supported by research Neves et al. (2016) and Dominicis et al. (2008). Economic theory does not unambiguously predict the direction of the effect of inequality on economic growth. Inequality possible that effect growth in different ways and through different channels.A single pattern for the inequality-growth relationship does not 
exist. Instead, we should take into consideration the existence of specific and particular effects that differ from region to region and that vary with the type of inequality and the time span considered.

Economic growth significant negative effect against the inequality is supported by Antonescu (2012), Yuliani (2015). Spread effect that shows the situation in which the development of underdeveloped regions (periphery) is driven by more developed regions (core). The spread effect that shows the situation in which the development of underdeveloped regions (periphery) is driven by more developed regions (core). Increased economic activity in the core region is expected to be able to increase performance economic in its own regions and spread in periphery regions by optimizing the existing source power potential. An increase in demand for agricultural and home industry products by core regions is a driving factor for the periphery regions to develop. Needed to attract, develop and optimize the role of investment in the periphery regions. Increased investment can spread the share of gross regional domestic products (stimulate the economic sector) and create broad employment opportunities in periphery regions. This will make a number of educated (quality) workers will survive to find work in periphery regions. In the end, inequality decreases.

\section{Conclusions}

The results showed that at the beginning of the observation period (2001-2008), spatial concentration tended to increase. The increase in spatial concentration reflects a decrease in the spread of the share of Regency and City Gross Regional Domestic Product (GRDP) in Central Java. After 2008 showed spatial concentration tended to decrease which meant that there was a share of the GDP. The same thing also happened in a number of regions within residencies and residencies in Central Java. Theil Enthropy Index Trends during the observation period in Central
Java was also supported by results that showed the relevance of economic growth and inequality fulfilled Kuznet's hypothesis.

Another finding is that only one-way relationships occur. The one-way relationship that occurs is economic growth towards inequality. Another important contribution is the effect of economic growth on inequality only in the long term. Thus, there has been convergence caused by an increase in economic growth so as to reduce inequality throughout the Central Java region including within-residency and between-Residency. This proves that during the implementation of regional autonomy there has been a spread effect impact greater than the impact of the backwash effect in Central Java including within-residency and between-Residency. In the future, the concept of spatial planning is needed to support the development of growth cores and peripheries, so that growth and equity can be carried out in a balanced manner.

In the core-periphery region, policies design to reduce inequality and increasing economic growth, so there is no trade-off. In particular, policy such as the promotion of more equitable tax and transfer systems, the implementation of labor market reforms aimed at reducing earning gaps and unemployment or the reduction of constraints to the access of credit markets. In addition, policies directed to promote a more equitable distribution of property, to improve the quality and reach of education and health to guarantee a more equitable distribution of educational and health opportunities. In sum, the redistribution strategy of growth will be more effective for equity.

Added other indicators such as economic and noneconomic (institutional) or/and using others method will be interesting for future research. The measurement method of inequality using entropy index can decomposition based on widly other category of region (such as development region based on law/regulation or classification based on region typology) or using proxy of others 
inequality.

\section{References}

Abdulah, R. (2013). Faktor-faktor yang memengaruhi ketimpangan pendapatan di jawa tengah. Journal of Economics and Policy, 6(1), 42-53. https://doi.org/http:// dx.doi.org/10.15294/jejak.v6i1.3747

Antonescu, D. (2012). Identifying regional disparities in Romania: a convergence process perspective in relation to European. Procedia - Social and Behavioral Sciences, 3(12), 1148-1155. https://doi.org/10.1016/ S2212-5671(12)00288-2

Arham, M. A. (2014). Kebijakan Desentralisasi Fiskal , Pergeseran Sektoral , dan Ketimpangan Antarkabupaten / Kota di Sulawesi Tengah Fiscal Decentralization Policies, Sectoral Shifts and Inequalities Amongst Regencies / Municipalities in Central Sulawesi Pendahuluan. Jurnal Ekonomi Dan Pembangunan Indonesia, 14(2), 145-167.

Aritenang, A. F. (2014). The spatial effect of fiscal decentralisation on regional disparities: the case from Indonesia. Indonesian Journal of Geography, 4(1), 1-11.

Arsyad, L. (2010). Ekonomi Pembangunan. Yogyakarta: STIM YKPN.

Bappenas. (2015). Kementerian PPN/Bappenas Gelar Rakor Evaluasi RPJMN 2010-2014 Dari Sisi Ketimpangan Pembangunan. Retrieved February 20, 2017, from Badan Perencanaan Pembangunan Nasional website: http://www.bappenas.go.id/id/ berita-dan-siaran-pers/kementerianpnbappenas-gelar-rakor-evaluasi-rpjmn2010 - 2014 - dari - si si - ketimpangan pembangunan/

Baransano, M. A., Putri, E. I. K., Achsani, N. A., \& Kolopaking, L. M. (2016). Analysis of Factors Affecting Regional Development Disparity in the Province of West Papua. Journal of Economics and Development Studies, 4(2), 115-128. https://doi. org/10.15640/jeds.v4n2a10

Bonet, J. (2006). Fiscal decentralization and regional income disparities: Evidence from the Colombian experience. Annals of Regional Science, 40(3), 661-676. https:// doi.org/10.1007/s00168-006-0060-z

Cahyono, H., Subroto, W. T., \& Anwar, K. (2017). Income Disparity in Gerbangkertosusila Area of East Java Indonesia. International Journal of Economics and Financial Issues, 7(1), 14-18.

Dhyatmika, K. W., \& Atmanti, H. D. (2013). Analisis Ketimpangan Pembangunan Provinsi Banten Pasca Pemekaran. Diponegoro Journal of Economics, 2(2), 1-8.

Đoki, I., Fröhlich, Z., \& Bakaric, I. R. (2016). The impact of the economic crisis on regional disparities in Croatia. Cambridge Journal of Regions, Economy and Society, 9(1), 179195. https://doi.org/10.1093/cjres/rsv030

Dominicis, L. De, Florax, R. J. G. M., \& Groot, H. L. F. De. (2008). a Meta-Analysis on the Relationship Between Income Inequality and Economic Growth. Scottish Journal of Political Economy, 55(5), 654-682. https:// doi.org/10.1111/j.1467-9485.2008.00470.x

Ezcurra, R., \& Pascual, P. (2008). Fiscal decentralization and regional disparities : evidence from several European Union countries. Enviroment and Planning, 40(1), 1185-1202. https://doi.org/10.1068/a39195

Fadli, F. (2014). Analysis of Direct and Indirect Effect of Fiscal Decentralization and Regional Disparity ( Case Study Provinces in East and West Indonesia Year 2006-2012 ). Journal of Economics and Sustainable Development, 5(18), 45-56.

Fitrawaty, Maipita, I., Hermawan, W., \& Rahman, H. (2018). The Impact of Middle-Class towards Economic Growth and Income Inequality in Indonesia. Jurnal Ekonomi Malaysia, 52(3), 1-14.

Gujarati, D. N., \& Porter, D. C. (2009). Basic of 
Econometric (5th ed.). New York: McGrawHill Education.

Habanik, J., Hostak, P., \& Kutik, J. (2013). Economic and Social Disparity Development Within Regional Development of The Slovak Republic. Economics and Management, 18(3), 457-464.

Islam, N., \& Noman, A. N. K. (2015). Estimated Regional Disparity for Northern Bangladesh. IOSR Journal of Humanities and Social Science, 20(11), 59-63. https:// doi.org/10.9790/0837-201115963

Isnowati, S. (2007). Pengujian Hipotesis Kuznet di Wilayah Pembangunan I Jawa Tengah. Jurnal Bisnis Dan Ekonomi, 14(1), 1-14.

Kuncoro, M. (2011). Metode Kuantitatif: Teori dan Aplikasi untuk Bisnis dan Ekonomi. Yogyakarta: UPP STIM YKPN.

Kuncoro, Mudrajad. (2013). Mudah Memahami dan Menganalisis Indikator Ekonomi. Yogyakarta: UPP STIM YKPN.

Kurniawan, B. R. A., \& Sugiyanto, F. X. (2013). Pengaruh Pertumbuhan Ekonomi, Share Sektor Industri Dan Pertanian Serta Tingkat Jumlah Orang Yang Bekerja Terhadap Ketimpangan Wilayah Antar Kabupaten/Kota Di Jawa Tengah Tahun 2002-2010. Diponegoro Journal of Economic, 2(1), 1-14.

Mahardiki, D., \& Santoso, R. P. (2013). Analisis perubahan ketimpangan pendapatan dan pertumbuhan ekonomi antar propinsi di indonesia 2006-2011. Journal of Economics and Policy, 6(2), 180-193. https://doi. org/10.15294/jejak.v7i1.3596

Neves, P. C., Afonso, Ó., \& Silva, S. T. (2016). A Meta-Analytic Reassessment of the Effects of Inequality on Growth. World Development, 78, 386-400. https://doi. org/10.1016/j.worlddev.2015.10.038

Nugroho, B. S. (2014). Pertumbuhan Ekonomi dan Ketimpangan Pendapatan Antar Kecamatan. Journal of Economics and Policy2, 7(1), 46-59. https://doi. org/10.15294/jejak.v7i1.3842

O'Hara, P. A. (2008). Principle of Circular and Cumulative Causation: Fusing Myrdalian and Kaldorian Growth and Development Dynamics. Journal of Economic Issues (Association for Evolutionary Economics), 42(2), 375-387. https://doi. org/10.2307/25511322

Panjawa, J. L., Samudro, B. R., \& Soesilo, A. M. (2018). Regional Economic Disparities in Eastren Indonesia and Determinants: Comparative Analysis of Origin District and New District. Region, 10(1), 117-124.

Postoiu, C., \& Bușega, I. (2015). Inter-Regional Disparities In The European Union. Romanian Review of Regional Studies, XI(1), 15-17.

Ramos, P. N., \& Coimbra, C. (2009). The Income Inter-Regional Redistribution And The Income Spatial Stabilization Effects: An Application To Portugal. Regional Science Inquiry, 1(1), 35-44.

Rodriguez-Pose, A., \& Ezcurra, R. (2010). Does decentralization matter for regional disparities? A cross-country analysis. Journal of Economic Geography, 10(September 2009), 619-644. https://doi. org/10.1093/jeg/lbp049

Rustiadi, E., Saefulhakim, S., \& Panuju, D. R. (2011). Perencanaan dan Pembangunan Wilayah. Indonesia: Yayasan Pustaka Obor Indonesia.

Samudro, B. R., Bloch, H., \& Salim, R. (2015). The uneven regional pattern of ecological capital in Indonesia: a political economy perspective. International Journal of Green Economics, 9(3/4), 258-272. https://doi. org/10.1504/IJGE.2015.075200

Shobha, K., \& Ambiga Devi, P. (2014). Inter State Disparities in India: Linkages between Human Development and Economic Indicators. Global Economics, 
2(3), 14-16. Retrieved from http://dx.doi. org/10.4172/2375-4389.1000121

Suseno, D. A. (2015). Pengembangan daerah berdasarkan tipologi pertumbuhan ekonomi dan ketimpangan sektor di wilayah kedung sepur. Journal of Economics and Policy, 8(1), 54-61. https://doi.org/10.15294/jejak. v7i1.Journal

Wijerathna, D., Bandara, J. S., Smith, C., \& Naranpanawa, A. (2014). Regional Disparities in Sri Lanka: An Empirical Analysis. Asia-Pacific Development Journal, 21(2), 77-102.

Yang, Y., \& Greaney, T. M. (2017). Economic growth and income inequality in the AsiaPacific region: A comparative study of China, Japan, South Korea, and the United States. Journal of Asian Economics, 48. https://doi.org/10.1016/j.asieco.2016.10.008

Yuliani, T. (2015). Pertumbuhan Ekonomi dan Ketimpangan Pendapatan Antar Kabupaten di Kalimantan Timur. Journal of Economics and Policy2, 8(1), 45-53. https://doi.org/10.15294/jejak.v7i1.Journal

Zakaria, S. (2013). The Impact of Decentralization toward Regional Inequalities in Eastern Region of Indonesia. Journal of Economics and Sustainable Development2, 4(10), 7484.

Zhuang, J., Kanbur, R., \& Rhee, C. (2014). Rising Inequality in Asia and Policy Implications. In ADBI Working Paper (No. 463). https:// doi.org/10.2139/ssrn.2399298 